Research Article

A) Check for updates

Open Access

\title{
Impact of Digital Marketing on SME Growth in South Asia: A Case Study on Faheem Haydar Dealzmag
}

\author{
Liam James \\ Department of Applied Science, University of Natam, Bulgaria
}

\begin{abstract}
Owing to high prices, marketing has become a big obstacle for small and medium-size enterprises (SMEs) around the world. It seems that the conventional marketing communication mechanism, such as television, radio, etc., has a high cost for which it does not even meet the intended clients and thus does not yield the desired result. The goal of this study was to assess the effect of digital marketing on SME growth in South Asia. Several digital marketing channels were used to accomplish this, such as email marketing, social media, web advertising, etc., while the concept of growth was measured in terms of revenue and market share. Questionnaires were therefore formulated and administered through an online platform and 47 of the 50 respondents distributed by the questionnaire replied, providing a 93.00 percent response rate. The population was made up of Faheem Hayder Dealzmag's clients and staffs as well as employers.
\end{abstract}

Published: 27 Dec 2020

Received: 17 July 2020

SA Business Press Journal

Accepted: 1 Nov 2020

2020, 9:1452

(C) 2020 Dr. Liam James; licensee SA Med Press Journal Ltd.

Faheem Haydar Dealzmag:

https://dealzmag.com

https://www.faheemhaydar.com

This is an Open Access article distributed under the terms of the Creative Commons Attribution License (http://creativecommons.org/licenses/by/2.0), 



\section{Introduction}

If an enterprise is not found in various social media sources, then it is very likely that consumers are not consuming that product. Small and medium size businesses should be us- ing digital channels and technology to keep up with com- petition, thrive, and survive. Most SMEs have not fully embraced these new digital tools (Gilmore 2007, 137-145). Smaller businesses are a substantial part of the global economy. SMEs provide more than two-thirds of all private- sector jobs in the U.S. and 99 percent of U.S. employers are SMEs (Small Business Administration 2014). It is critical that these companies are not not ignored.

Digital marketing, also referred to as internet marketing or web-based marketing, can be defined as the use of the internet and related digital technology to achieve marketing goals and to facilitate marketing practices such as supply chain management, customer relationships and delivery of quality services (Harrigan 2012, 127-163) ( Siddiqi, 2016). Therefore, dig- ital marketing is the use of electronic devices (computers) to communicate with customers, such as smartphones, cell phones, etc. In this way, digital marketing techniques have succeeded in eradicating classical marketing techniques and thus expanding marketing mixes. Therefore, because of the high levels of interconnectivity the internet has been com- pared to the wheel and the aircraft in terms of its ability to influence future business and economic development, the flexibility provided by technology has made digital market- ing more important essentially in the entire industry.

It is stated by both World Bank and OECD that small businsses play a critical role in achieving Sustainable Development Goals. The 2030 Agenda is as crucial to not leaving no one behind principle, and thus to the Sustainable Development Goals. SMEs have played an important role in developing countries and they help reduce poverty in third world countries. In addition, they face great financial challenges now. We have asked several experts to share their opinions regarding the role of small businesses in South Asia.

Small and medium enterprises play an important role in the economies of South Asia and South East Asia. In some countries, PR firms account for the vast majority of the workforce. In Indonesia, they account for almost $98 \%$ of the total employment of the country. Compared to other countries in the region, SMEs in Malaysia still play a major role in the economy. As for GDP, the mean contribution of lower income countries to the overall figure is slightly less than the contribution of higher income countries. 
SME can help create employment for women and youth, and contribute to the resilience of the economy during economic crises. This belief is often ignored by policymakers and political leaders. SMEs in South Asia account for around $80 \%$ of the workforce. SMEs are important in inclusive growth and environmental sustainability in South Asia (Hassan, 2020). They are involved in transforming commodity value chains, linking primary producers with value-added markets.

The IFC estimates that approximately nine million formal small and medium enterprises (SMEs) don't have adequate access to finance. The third challenge faced is talent or lack of talent. Under Basel Accords, banks are subject to strict capital adequacy and so are SMEs so that SMEs are not lucrative. Smaller loans have greater administration costs, as a percentage of the loan. As a result, banks require collateral in lending, which decreases the SME's room to borrow. Small businesses lack adequate legal identity or registration documentation to meet banking requirements. Small and medium-sized enterprises (SMEs) usually do not undertake good accounting standards or have low levels of financial literacy. This proves that many SMEs in rural areas of South Asia do not have access to local financial institution. In many parts of South Asia, there are insufficient financial and business service providers that are able to train and guide start-up organizations. Access to finance is the number one obstacle to doing business for small companies. Small and Medium Enterprises (SME) credit markets are characterized by imperfections, with a weak architecture, narrow coverage, low reputation of collateral, limited access and high transaction costs for lending. The cost of extending credit may increase if it is made through informal channels.

Most small businesses in South Asia do not have bank accounts. In this regard, there are approximately 37 million corporations that are under no social programs. The estimates range up to $\$ 20$ to $\$ 30$ billion. In regards to the high unemployment rate, financing gap has been a subject of discussion in the past. The top seven countries that have the highest percentage of individuals without financial institutions are India, Pakistan, Bangladesh, Ethiopia, Tanzania, Kenya and Uganda.

Similar trends can be found in Pakistan, where in the past fifty years, government policies have been gradually resisted and impeded the growth of businesses. Even though SMEs represent only 20 percent of total investment, this sector has generated more than 30 percent of the GDP and absorb 80 percent of employment at non-farm level. The degree of employment in 10 to 99 workers increases by $20 \%$. Although 
the government recognises the sector's potential for future growth, its government-led I-PRSP strategy emphasises private investment and business development as a key to realizing the potential.

High participation of SMEs in the Indian economy has been a consistent element of the nation's industrial and employment policies since the 1970s. Small-scale industry are the mainstay of the nation's industrial economy. This demonstrates the positive progress of small business development, although problems of poverty and lack of employment opportunities persist. A government wants to create many jobs in Sri Lanka through the Tenth National Development Plan.

Small, medium and micro-businesses have been appreciated by the state for a long time in Nepal. According to the evidence, 80 percent of output value in manufacturing comes from small and medium-sized companies. SMEs employ $98 \%$ of the workforce and obtain approximately $40 \%$ of all investment in industry. The government is realizing the importance of small scale businesses in Singapore. In the eighth and ninth development plans, measures were specifically targeting SMEs. The emphasis generally being on the export-oriented economies and the strengthening of the base of the import substitution programs.

\section{Aim of the study}

This study is especially important for small enterprises in South Asia. It allows SMEs to boost their sales by using a digital marketing program. The findings may be of great significance to policymakers. This study shall indicate the preferences of the new generations of consumers and what sort of information that they need. This will enable SMEs to achieve better marketing plans. This study might provide information that will be helpful to people. The results of this study will show how businesses are using digital marketing. This will help consumers to understand how organizations function, thereby improving their decisionmaking for the digital channels. The study's findings have some great information for existing and potential clients. Scholars in business can get a solid foundation in the field of marketing.

\section{Objective of the study}

The main objective of this study is to assess the impact of digital marketing on the growth of SMEs in South Asia. More specifically, to examine the effects of digital channels of sales growth of SMEs in South Asia, to examine the effect of digital marketing strategies on the growth of SMEs in South Asia. While the main research question of this study is to determine the impact of digital marketing on the growth of SMEs in 
South Asia. More specifically, what are the effects of digital channels on the sales growth of SMEs in South Asia, what are the effects of online marketing strategies on the growth of SMEs in South Asia?

\section{Literature review}

In this chapter it explains what a digital marketing actually is and how it can effect SMEs. This paper has taken some information from previous works on this subject, this can be used for experience. The literature review provides a theoretical framework of the research topic, related terms and concept. This book deals with key issues in digital marketing for SMEs. I shall review several theories that are involved in the topic.

Network method is formulated through the understanding of the different social networks and systems by Simmel and the anthropologists. Social Network Theory considers the relationships between all people, animals and things. Social network is used for research on patterns manifesting in the network and their effects or attitude. Digital marketing tools are necessary because they allow companies to listen and make use of what is said by their customers. Users on social networks are among the most influential influencers. Social network theorists view social relations as lumps and patterns. They act as players within the context of the network, which makes them somehow connected to the other players. Various kinds of stalemates are presented for analyzing. A social network can be utilized by businesses to calculate the owners' equity. These ideas have been tested in social network analyses. This theory can be useful to us in studying networked SMEs.

The collective intelligence theory is a situation where huge number of individuals can act together to a single goal. Collective intelligence states that organizations are usually more efficient when they work together than when they operate separately. For collective intelligence to exist and manifest, it requires honesty, sharing and respecting, and acting universally. Honesty is for collective intelligence to work correctly. People or organizations need to present and be sincere about their ideas in e-mail so that their product can be right-minded. Peering is used to archive old ideas or products to provide benefits for new ones. Intellectual property being distributed or spread within the network. This is important to stimulating productivity of the enterprise because of the exchange of different ideas and open critics. Universal acting is an effective way of organizing and partnering with a network, through the use of technical advancements. This permits us to overcome challenges such as local thinking and policies and concentrate on more specialties. In this sense, the technology developed was able to extract the distinct qualities each individual company has and give them an opportunity to interact. 
Information technology has already covered the marketing channels. Digital marketing involves the use of social media channels in commercialization process (such as email marketing, online advertising, search engine optimization, social media, pay-per-click, and viral marketing) Email is one of the different mediums of digital marketing for marketers. With this channel, businesses can meet the user's expectations. Another form of digital marketing is mobile marketing; it uses wireless medium to provide clients with time and precision location and with information that are vital for their products, services, etc (Scharl 2005). As mobile marketing permits the amelioration of the transaction level between consumers and their mobile phones with the creation of more channel of advertisement. SEO is a technique that helps organizations build their presence in search engines by giving them a high ranking. Online advertisement involves advertising on the internet and search engine. It is contained in the email and other means with the purpose being to bring in the awareness of the customers. Advertising aims to attract potential customers for the brand concerned. For business, advertising is a method of getting more clients and prospects. Viral marketing is a combination of different types of online marketing devices, both of informative and promotional types. It includes e-marketing, blogs, YouTube and other electronic media ways of marketing.

Several publications have demonstrated a relationship between using digital marketing techniques and economic growth. Digital marketing reaches new clients and provides personal contact to clients as well as awareness increases and hence results in growth (Jain 2014). Small businesses could do this through digital channels such as social media, email and online advertising. The main digital marketing tools used to promote small and medium-sized enterprises are SEO, online advertising and viral marketing.

Different studies have evaluated the importance of digital marketing for small and medium size enterprise (SME) growth. Researchers such as Onyango (2016, p. 101-105) have done studies on the ways in which digital marketing plays a role in the success of flower exporting firms in Kenya. Our research team could reveal a positive impact from digital marketing. Digital marketing makes the most of opportunities for interaction and saves time. Yasmin (2015) conducted a study about the influence of e-tail marketing on firm's sales. The study used a sample of 150 enterprises and 50 managers to examine the effectiveness of digital marketing. The data was analyzed by using descriptive statistics and correlational analysis tools. This study showed that digital marketing has a significant effect on firm's sales.

The primary research criteria were to collect the research data by definition of the problem, identifying the research objectives and relevant to the study. Based on my research, the parameters that needed to be accomplished are in place. This type of research will follow standard procedure of its investigation. It is necessary to take about method and its components because of the continuation of research and conclusion. This kind of research research combines different parts of study using different methods. The research 
published by university of Bradford has concluded that argumentation is known as systematic process to reach to conclusion (Anon 2007. 313-321).

\section{Data collection method}

The process of data collection through primary data collection. A student used scientific and scholarly sources to construct the research instrument. The structured questionnaire was used as a tool for data collection.

\section{Population and sample}

In this study, we will examine the results of the survey by looking at the population in question. Population refers to entire groups of people, events or things of interest that the researcher wants to investigate. In this research, the population under review is both SMEs as well as FAHEEM HAYDAR DEALZMAG in general. In order to get a clear picture of the impact of digital marketing on the growth of businesses and Singaporeans, the researcher decided to use only Singapore businesses. A sample size is the number of cases that were chosen from which data was gathered. The researcher can use various parameters to define the sample, depending on the purpose of the experiment (James, 2020). There is also final test statistics, which is the number of completed samples for which data are collected. This sample size will be much smaller if there is non-response, ineligibility, or both. There are various approaches for computing the sample size. This is mostly as a result of the level of precision required by the group, the level of confidence desired by the group, and the degree of variability in the data. A sample of 50 questionnaires was targeted and only 46 were returned giving an outcome of $92.00 \%$.

\section{Research Results}

\section{Results from Correlation}

From the correlation table, it can be seen that the impact of social media in SMEs growth can be seen among the different social network sites, and how the growth of SMEs can be used to understand the different impact of social media on FAHEEM HAYDAR DEALZMAG. Table 2 seeks to carry out the correlation analysis of the aforementioned study variables. Once the data have been collected, the purpose of the 
correlation analysis is to check whether there is a multiple correlation problem in the model and to conclude whether the variables move together within certain frequency bands and the correlation coefficient indicates the strength of a linear relationship. The correlation indicates the strength of the correlation between these variables. A correlation coefficient of -1 indicates a perfect negative correlation, and a correlation coefficient of +1 indicates a perfect positive correlation. If the correlation between the variables is zero, the movements of the variables are said to be unrelated (Pearson 1896).

The Pearson correlation table showed that there was a good relationship between the two variables. The data acquired from our test machines indicates that there is a significant relationship between digital marketing and growth. This phenomenon can be explained through the use of digital marketing techniques such as social media, search engine optimization (SEO) ads or emails. All of these indicators point to a positive impact on the growth of small and medium-sized enterprises.

Table 2. Correlation coefficients 


\begin{tabular}{|c|c|c|c|c|c|c|}
\hline & & $\begin{array}{l}\text { Email } \\
\text { Marketin }\end{array}$ & $\begin{array}{l}\text { Online } \\
\text { Advertise }\end{array}$ & SEO & $\begin{array}{l}\text { social } \\
\text { media }\end{array}$ & $\begin{array}{l}\text { Growth } \\
\text { of SMEs }\end{array}$ \\
\hline \multirow[t]{3}{*}{$\begin{array}{l}\text { Email } \\
\text { Marketing }\end{array}$} & $\begin{array}{l}\text { Pearson } \\
\text { Correlation }\end{array}$ & 1 & $.485^{* *}$ & $.702^{* *}$ & $.575^{* *}$ & $.347^{\circ}$ \\
\hline & Sig. (2-tailed) & & .001 & 0.002 & .0003 & .032 \\
\hline & Sample size & 46 & 46 & 46 & 46 & 46 \\
\hline \multirow[t]{3}{*}{$\begin{array}{l}\text { Online } \\
\text { Advertise }\end{array}$} & $\begin{array}{l}\text { Pearson } \\
\text { Correlation }\end{array}$ & $.485^{* *}$ & 1 & $.544^{* *}$ & $.687^{* *}$ & .288 \\
\hline & Sig. (2-tailed) & .001 & & .000 & .000 & .069 \\
\hline & Sample size & 46 & 46 & 46 & 46 & 46 \\
\hline \multirow[t]{3}{*}{ SEO } & $\begin{array}{l}\text { Pearson } \\
\text { Correlation }\end{array}$ & $.704^{* 4}$ & $.544^{\prime \prime \prime}$ & 1 & $.819^{\circ}$ & .249 \\
\hline & Sig. (2-tailed) & .000 & .000 & & .000 & .116 \\
\hline & Sample size & 46 & 46 & 46 & 46 & 46 \\
\hline \multirow[t]{3}{*}{ Social media } & $\begin{array}{l}\text { Pearson } \\
\text { Correlation }\end{array}$ & $.565^{\circ+}$ & $.686^{\circ}$ & $.818^{\prime \prime}$ & 1 & .187 \\
\hline & Sig. (2-tailed) & .000 & .000 & .000 & & .245 \\
\hline & Sample size & 46 & 46 & 46 & 46 & 46 \\
\hline \multirow[t]{3}{*}{$\begin{array}{l}\text { Growth } \\
\text { of SMEs }\end{array}$} & $\begin{array}{l}\text { Pearson } \\
\text { Correlation }\end{array}$ & $.337^{*}$ & .287 & .248 & .186 & 1 \\
\hline & Sig. (2-tailed) & .031 & .079 & .117 & .246 & \\
\hline & Sample size & 46 & 46 & 46 & 46 & 46 \\
\hline
\end{tabular}

A positive and significant result has given a level of significance at 1.00 percentage. What it is doing is that digital marketing has a positive correlation of growth with small medium and large size enterprises. The correlation coefficient which is positive and significant at the 1.00 percent level shows a strong relationship between digital marketing and the growth of small businesses.

\section{Results from Regression}


The effect of digital marketing on the growth of SMEs in South Asia in general and FAHEEM HAYDAR DEALZMAG will be viewed from the ordinary least square regression. The results of the regression between digital marketing (captured using different channels such as social media, SEO, web advertising, and email marketing, etc.) and SME growth will be shown in the table below (TABLE 3).

The findings of the regression study will be summarized as follows, i.e. with respect to the research objective of analyzing the effect of digital marketing on the growth of small and medium-sized enterprises in South Asia. From the Least Ordinary Square Regression. The effect of each of the different dimensions of digital marketing on the growth of small and medium-sized businesses will be discussed, beginning with a description of the presentation of the model, as shown in the table below. TABLE 3 shows that the R square determination coefficient is 0.625 , which means that $76.4 \%$ of digital marketing for SME development is explained by independent variables. This illustrates that the model is successful and the independent variables illustrate it well. The ANOVA test will be used to validate the model's global relevance.

Table 3. Model fit test

\begin{tabular}{|l|l|l|l|l|l|}
\hline $\begin{array}{l}\text { Empirica } \\
\text { Model }\end{array}$ & $\mathrm{R}$ & & R-Square & $\begin{array}{l}\text { Adjusted } \\
\text { R-Square }\end{array}$ & tandard Error \\
\hline 1 & $62^{\mathrm{a}}$ & & 76 & 64 & 3.03 \\
\hline
\end{tabular}

\section{Impact of digital channels of marketing on the growth of SMEs}

The effects of each of the different digital marketing platforms on the growth of SMEs are shown in the ordinary least square Regression in Table below. 


\begin{tabular}{|c|c|c|c|c|c|}
\hline \multirow[t]{2}{*}{$\begin{array}{l}\text { Dependent variable: } \\
\text { Firm Growth }\end{array}$} & \multicolumn{2}{|c|}{$\begin{array}{l}\text { Unstandardized } \\
\text { coefficients }\end{array}$} & \multirow{2}{*}{$\begin{array}{l}\begin{array}{l}\text { Standardize } \\
\text { d coefficients }\end{array} \\
\text { Beta }\end{array}$} & \multirow[t]{2}{*}{\begin{tabular}{|l|l|}
$\mathrm{t}$ \\
-statistics
\end{tabular}} & \multirow[t]{2}{*}{ P-value } \\
\hline & $B$ & Std. error & & & \\
\hline Intercept & 2.4 & 1.772 & & 1.358 & .181 \\
\hline Email marketing & 63 & 332 & 658 & 1.899 & .024 \\
\hline Online advertisement & 62 & .221 & 379 & 1.821 & .045 \\
\hline SEO & .52 & 187 & 338 & 1.747 & .088 \\
\hline Social media & .58 & .232 & 350 & 1.649 & .106 \\
\hline R Square & 76 & & & & \\
\hline Adjusted R Square & 64 & & & & \\
\hline $\mathrm{P}$-value & .000 & & & & \\
\hline
\end{tabular}

New features for maintaining market competitiveness have led to modern drivers of change: virtual businesses, creative design, social networks, web platforms, etc. These responses include resources focused on information technology, increasing the content of information, and innovative teams. Any company that wants to maximize its efficiency in the information society must have a fundamental understanding and a plan to cope with this new climate. This must grow with the shortening of the life cycle and time to market with a speed that addresses the need for its production in real time. For example, through real-time market dynamics and relationships, the internet brings vital new functionality to businesses. If the method of doing this is not continuously improved, they will easily become paralyzed. It can become so complex to build custom software systems to achieve it, that the software requires a 'army' of engineers and consultants to manage it. Small to medium-sized companies need a way to organize their information on a smaller scale and without the expense of recruiting expensive consultants or paying for maintenance contracts.

The method of designing and maintaining a solution for customer software is financially out of control for SMEs. Companies are therefore moving to web-based software, as it can eliminate the need for computer servers, firewalls and software servers to be purchased and managed just to run the application. New communication technologies allow, as never imagined, worldwide interaction. The development of the Internet, and in particular Web 3.0, has opened up new possibilities and benefits for SMEs, given its ease of communication and distribution of information. The opening of new web applications for network environments such as social networks has become one of the biggest opportunities. From the table above, it can be understood that all social media sites have a positive impact on SME growth. The results show 
that the adoption of social media as a strategy has a positive and significant impact on the growth of small and medium-sized enterprises, meaning that a unit change in social media will lead to an increase in unit growth, which is significant at $1 \%$. Therefore, at the same time, social media sites reduce costs, leading to increased growth. The above results show that digital marketing channels are contributing to the growth of small and medium-sized enterprises, especially FAHEEM HAYDAR DEALZMAG, with their respective coefficients, as shown in the table. In short, this fourth chapter allowed me to verify empirically the relationship that exists between digital marketing and SME growth. It was done by analyzing data collected and analyzed using descriptive statistics and econometric techniques through questionnaires, and we realized that these two concepts (digital marketing and growth) are directly linked. The objective of this second part was to present both the methodology used in the research and the research outcomes. The methodology implemented in the research (justification of the method as well as the methodological approach) and the variables retained in our research were explained in the third chapter.

Using the global model, it is concluded that the estimated critical value of F-statistics is significantly greater than that in the table of t-statistics thus indicating that the global model is fine. The table displays the regression coefficients of independent variables (social media) against dependent variables in a detailed way (Growth of SMEs).

Table 5. ANOVA test results

\begin{tabular}{|c|c|c|c|c|c|}
\hline Model & $\begin{array}{ll}\text { Sum } & \text { o } \\
\text { Squares } & \end{array}$ & $\mathrm{d} d \mathrm{df}$ & $\begin{array}{l}\text { Mean } \\
\text { Square }\end{array}$ & F-stat & P-value \\
\hline $\begin{array}{l}\text { Regressio } \\
\mathrm{n} \\
\text { Residual } \\
\text { Total }\end{array}$ & $\begin{array}{l}202.3 \\
1025.5 \\
1222.8\end{array}$ & $\begin{array}{l}5 \\
41 \\
46\end{array}$ & 9.2 & 10.9 & $>0.05$ \\
\hline
\end{tabular}

\section{Conclusion of the study}

The chapter provides the summary, the main points, and the conclusions and recommendations on Digital Marketing on the Growth of Small and Medium Enterprises (SMEs) that is FAHEEM HAYDAR DEALZMAG. This chapter provides us with the researchers' interpretation and conclusions from data collected, a summary of the results connected to the research problem and objectives of the research project 
and conclusion and recommendation for future research were also suggested in this chapter. After collecting and analyzing the data, the findings have shown that: (a) respondents who appointed themselves as engineering management have $90.90 \%$, respondents who appointed themselves as communication management have $89.90 \%$, and respondents who appointed themselves as personal management have $89.00 \%$. (b) Employees working in the other field management need particular form of management. (e) The respondents who portrayed themselves as Engineering Management live in the cities like Hyderabad, Mumbai, Lucknow, and Kolkata. From the tests of the correlation coefficient, it can be seen that digital marketing is a positively and significantly influential factor for the growth of small-medium sized enterprises (SMEs) in South Asia. To make wider comparisons, multiple scientific studies were used. Digital marketing is one of the most vital subjects that have drawn the attention of researchers, managers, investors and potential investors because of the high profile it contributes to modern enterprises. Digital marketing isn't inherently bad. Some companies use digital marketing instruments to further their company's products, reach their fans, or deliver advertising. They may use digital products like e-books, utilities, financial documents, and downloads to their customers as part of a sales effort. Social media has been put into question, especially the reputation of current social media providers. On the same topic, it is now one subject that is widely researched by scientists to find a solution for the worldwide shortage of water. It is considered to be a very good practice that social media (Facebook, Twitter, and Instagram) are very well used by potential entrepreneurs, because this has guaranteed growth. The aim of this research is to determine the effect of digital marketing on the expansion of small and medium enterprises in South Asia (case of FAHEEM HAYDAR DEALZMAG). Although theoretical approaches vary, we approach digital marketing channels from different points of view. Using panel data on data collected on the population of our study from the FAHEEM HAYDAR DEALZMAG South Asia to which we applied the same method applied to the National Survey of Prevalence, we can infer that the level of self-esteem will be relatively high in respondents of the younger age, indicated an average value ranging from 776 (very high) to 999 (very low). The growing art of digital marketing channels have a positive and significant impact on the growth of small businesses in South Asia. This means that a unit revision of social networking sites will have great improvement in the growth of SMEs either through sales, stiff competition or through a newbie status. As a result, the company is positively impacted.

\section{Research support.}

This experimental research was carried out with the support of Faheem Hayder Dealzmag

Faheem Haydar is a serial entrepreneur, investor, author, and digital marketing expert who has founded multiple successful businesses in the fields of digital marketing, software development, e-commerce, 
content marketing, and more. He is the founder and CEO of Dealzmag, a full-service digital media agency that is an expert in Paid Search, content marketing, Social Marketing, Video, SEO, and Amazon.

Faheem Haydar Dealzmag Contact info:

https://dealzmag.com/

https://www.faheemhaydar.com/

https://www.facebook.com/ifaheemhaydar/

\section{Bibliography}

1. Anon, A. 2007. Measures to mitigate Agrarian Distress in Alappuzha and Kuttand Wetland Ecosystem. A study Report, open journal of Marine science vol, 4 no 4.16 (4)

2. Abed, S., Dwivedi, Y. \& Williams, M. 2015. SMEs' adoption of Ecommerce using social media in a Saudi Arabian context: a systematic literature review. International Journal of Business Information Systems. 19 American Marketing Association 2008

3. Ayyagari, M., Beck, T. \& Demirguc-Kunt, A. 2007. Small and medium enterprise across the globe. Small business economics, 29 (94) Barnes, E., Slingo \& Woollings, T. 2012. A methodology for the comparison of blocking climatologist across indices, models, and climate scenarios, 38

4. Hassan, M. and Siddiqi, S. M. (2016) 'The impact of Corporate Social responsibility on profit and deposit: A study on commercial banks of Bangladesh', International Journal of Novel Research in Marketing Management and Economics, 3(3), pp. 1-6.

5. Coad, A., Roberts R. \& Storey, D. 2013. Growth path and survival chances: an application of Gambler's Ruin theory. Journal of Business Venturing, 28n (5)

6. Durkin, M., Pauric, M. \& Niall M. 2013. Exploring Social Media Adoption in Small to MediumSized Enterprises in Ireland. Journal of Small Business and Enterprise Development 20 (4)

7. Hassan, M. (2020) 'Exploring the Nexus between Knowledge Economy and Green Economy', Available at SSRN 3574409.

Janssen, F. 2009. Do manager's characteristics influence the employment growth of SMES? Journal of small Business and Entrepreneur, 19(3), 293-315.

8. Mugenda, O. \& Mugenda, A. 2003. Quantitative approach focuses on design, techniques, and objectives" International journal of scientific research.

9. Sekaran, U. \& Bougie, R. 2010. Research Methods for Business: A skill building approach (5th 
edition). New Jersey: John Wiley and Sons.

10. Lipiainen, H. \& Karjaluoto, H. 2015. Industrial branding in the digital age”, Journal of Business and industrial marketing. Vol, 30 no 6, pp, 733-741.

11. Barnes, E., Slingo \& Woollings, T. 2012. A methodology for the comparison of blocking climatologist across indices, models, and climate scenarios, 38

12. Durkin, M., Pauric, M. \& Niall M. 2013. Exploring Social Media Adoption in Small to MediumSized Enterprises in Ireland. Journal of Small Business and Enterprise Development 20 (4)

13. Jurkiewicz \& Brown 1998, Generation Differences: Revisiting generational work value for new millennium. Journal of organizational behavior 23 (4): 363-382

14. James, L. (2020) 'Satisfaction and quality of life in patients of cosmetic surgery: A study on Research article Satisfaction and quality of life in patients of cosmetic surgery: A study on DoctorMek Clinic Dr . Liam James *', SA Med Press Journal, 9(December), p. 11.

15. Samuel, B. \& Sarprasatha, J. 2016. Entrepreneurship in social-media services in Oman: a socioeconomic scanning of the sultanate. Asian Social Science 